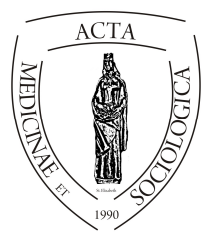

\title{
NetWorking 2.0 \\ Migránsok kapcsolathálózatának vizsgálata PSN-térkép,- és interjú módszerrel
}

\author{
Szabó Dóra ${ }^{1}$, Szabó Miklós² \\ ${ }^{1}$ doktorandusz, ELTE TáTK, Szociológia Doktori Iskola- Interdiszciplináris Társadalomkutatások Program, Buda- \\ pest, Pázmány Péter stny. 1/A, 1117 \\ ${ }^{2} \mathrm{BA}$ szociológia hallgató, ELTE TáTK, Budapest, Pázmány Péter stny. 1/A, 1117
}

\section{INFO}

Dóra Szabó

doriszabo1992@gmail.com

Miklós Szabó

szabo.miklos.1998@gmail.com

\section{Keywords}

Hungary,

Netherlands, migration, social network, PSN-map,

\section{ABSTRACT}

NetWorking 2.0. Examining the relation networks of migrants with PSN-maps and interview method. "The social network, especially our strong ties, have a large - scale influence on our attitude and general behavior (...) Through our friends, next to getting material, and immaterial goods, valuable social connections are available, what can be very useful to have a good position in the society, with far-reaching social network.” (Barabási, 2013)

The importance of social connections have an unquestionable role to integrate the individual into the society. One of the most current categorisation of social relationships is connected to the name of Granovetter, who made a difference of strong and weak ties in the terms of timeperiod, emotional intensity and mutual services of the relationships. In the study of Getting a job he emphasized the role of weak ties in the process of integration into the labour market. This is one of the most important goals in case of economical migration, and also a necessarily fact to be accepted by the host-society.

During the migration process the person usually leaves all the friends, family, and the whole social network,- what was owned in the origin country - behind. With the process of acculturation the structure of the network is changing, just like the functions of the alters.

The first stage of the study was to discover the composition of the personal social network of young regular migrants, who moved to the Netherlands more than 1 year ago, and successfully integrated him/herself into the labour market. The categorisation of the social ties are divided one hand into veryclose and somewhat-close relationships, based on criteria of 
different researchers. On the other hand host, origin, transnational and fellows categories, based on the origin- and current country of the alters. In 2016 the research involved 7 foreign and also 6 Dutch (Host) participants (Szabó, 2017).

From 2017 September, we continued the research in Hungary with involving 30 more young regular migrants. By using the same interactive method of personal social networkmap it is possible to get information of the functions, closeness, and above mentioned types of the ties. The combination with a qualitative interview helps the complexity of the network, and adds information of the level of subjective integration, and the role of social connections by the mechanism of finding a job.

This analysis is based on the network maps, which has been asked in the Netherlands (2016) and Hungary (2017) from young ( under 35 years old) regular migrants. The focus of the research is on the size and structure of social networks by both focus groups. The results showed a very interesting difference in size and in composition of the networks by the focus groups.

\author{
Kulcsszavak \\ Magyarország, \\ Hollandia, \\ migráció, \\ kapcsolatháló, \\ PSN-térkép,
}

Absztrakt. A migráció kérdése- különösen az elmúlt évben, - de napjainkban is folyamatosan napirenden van. Bár a migrációs hullám radikálisan, és speciális módon érintette Magyarországot, hazánk megmaradt tranzit-ország szerepben, hiszen a menekültek szignifikáns hányada nem szándékozott tartósan letelepedni (Juhász- Molnár, 2016; TÁRKI, 2016; Szabó, 2016).

Ennek ellenére, a bevándorlási hullám és az ehhez kapcsolódó politikai kampányok erőteljesen formálták a hazai közvéleményt, és döntően két radikális- politikailag befolyásolt ellenpólus jelent meg: az egyik oldal állítása szerint a migrációs hullám kulturálisan, és személyes biztonság tekintetben is veszélyezteti az országot (kontinenst), a másik oldal szerint pedig, tulajdonképpen egy nem létezö, politikailag generált problémáról beszélünk (Juhász- Molnár, 2016).

A magyar társadalom idegen-ellenes attitüdjét több nemzeti, és nemzetközi tanulmány is bizonyítja (pl. TÁRKI, EUROBAROMÉTER).

A TÁRKI által mért idegenellenesség 2012 és 2015 közötti - a korábbi évekhez képest eleve magasabb - értéke 2016 januárjára tovább növekedett, miközben a mérlegelők aránya a valaha mért legalacsonyabb szintre esett vissza, valamint az idegenbarátok aránya a nullához közelített.

2016-ban, 13 résztvevő bevonásával, az anti-xenofób országként számontartott Hollandiában letelepedett fiatal külföldi munkavállalók befogadó társadalomba való beágyazottságát vizsgáltam a kapcsolat rendszerükön keresztül, amihez a Lubbers és Molina $(2007 ; 2010)$ által használt PSN-térkép és interjú módszerét alkalmaztam.

Ezúttal a kutatást hazai terepen folytattuk, Magyarországon élö, munkaviszonnyal rendelkező, 35 év alatti fiatalok körében, akiket hólabda módszerrel vontunk be. 
A 2015-ös migrációs válság hatására tovább növekedett (minden rekordot megdöntött) xenofóbia, elöítéletesség (TÁRKI, 2016) természetesen gátolja a társadalmi integrációt, valamint a külföldiek lehetőségét a host-országbeli kapcsolatok kialakítására, ami különböző kulturális-gazdasági-társadalmi javak (Bourdieu, 1987, Granovetter 1973, 1974, Angelusz \&Amp; Tardos 1998; Gyarmati 2009; Dávid- Huszti- Lukács, 2016) áramoltatásán túl, hozzájárulhatna az egyén szubjektív jóllétéhez (Utasi, 1999, 2004; Albert - Dávid, 1999, 2004, 2007, 2016; Dávid - Huszti - Lukács, 2016; etc.). A vizsgált fiatalokat fokozottan érinthetik az elóitéletekre alapozott sztereotípiák, ennek következtében a kirekesztés, emellett az aktív- fizikailag is elérhető kapcsolatok hiányában az izoláció.

Bár a kutatást még nem tekintjük befejezettnek, az adatok elemzése pedig folyamatban van, jelen tanulmányban beszámolunk a magyarországi lekérdezés részeredményeiről, a kapcsolati háló méretét, illetve a Host-Origin-FellowsTransnationals kapcsolatok arányának megoszlását illetően.

Ez a tanulmány a XI. Nyíregyházi Doktorandusz Konferencián (2017. 12. 01., Nyíregyházi Egyetem) elhangzott előadás alapján készült.

\section{Bevezetés helyett: Migráció- Idegenellenesség}

A migráció kérdésének aktualitása megkérdőjelezhetetlen. Bár napi szinten értesülünk a legkülönfélébb forrásokból az európai bevándorlással kapcsolatos hírekről, a 2015 nyarán kirobbant migrációs válság kapcsán kevés szó esik arról, hogy a nemzetközi migráció volumene, intenzitása folyamatosan nő- írja a Migráció Kutató Intézet (2017) (Melléklet I.- 1. ábra). A folyamat természetesen multifaktoriális okokra vezethető viszsza. Egyrészről a globalizáció, másrészt a mobilizációs csatornák kiszélesedése (Migráció Kutató Intézet, 2017, http1), az általunk vizsgált reguláris migránsok esetében pedig döntően gazdasági tényezők játszanak szerepet az anyaország elhagyásában.

Bár a 2015-ös migrációs hullám radikálisan, és speciális módon érintette Magyarországot, hazánk megmaradt tranzit-ország szerepben, hiszen a menekültek szignifikáns hányada nem szándékozott tartósan letelepedni (Juhász-Molnár, 2016, TÁRKI, 2016, Szabó, 2016). Ennek ellenére a bevándorlási hullám, és az ehhez kapcsolódó politikai kampányok erőteljesen formálták a hazai közvéleményt, és döntően két radikális- politikailag befolyásolt ellenpólus jelent meg: az egyik oldal állítása szerint a migrációs hullám kulturálisan, és személyes biztonság tekintetében is veszélyezteti az országot (kontinenst), a másik oldal szerint pedig, tulajdonképpen egy nem létező, politikailag generált problémáról beszélünk (Juhász- Molnár, 2016).

2013 májusában a Standard EUROBAROMÉTER felmérése által megkérdezett magyarok csupán 7\%-a gondolta, hogy a migráció az Európai Unió egyik legfontosabb problémai közé tartozik. 2015 novemberére a migráció- kérdése az első helyre került az EU kihívások listáján, az aránya pedig, 18\%-ról (2014) 68\%-ra emelkedett egyetlen év 
alatt. Szorosan követte a lista második helyén a terrorizmus elleni küzdelem (JuhászMolnár, 2016).

A magyar társadalom idegen-ellenes attitüdjét több nemzeti, és nemzetközi tanulmány is bizonyítja (pl. TÁRKI, EUROBAROMÉTER). Szintén magas arányban van jelen az intolerancia az országban, elsősorban azon csoportokkal szemben, amelyekhez ijesztő sztereotípiák kapcsolódnak, és amely csoportok félelmet keltenek a többségi társadalomban (TÁRKI, 2015). Ezek után nem meglepőek a statisztikák (TÁRKI, EUROBAROMÉTER), amelyek az idegenellenesség radikális növekedéséről számoltak be a bevándorlási hullám után.

A TÁRKI által mért idegenellenesség 2012 és 2015 közötti - a korábbi évekhez képest eleve magasabb - értéke 2016 januárjára tovább növekedett, miközben a mérlegelök aránya a valaha mért legalacsonyabb szintre esett vissza, valamint az idegenbarátok aránya a nullához közelített. (Melléklet II- 2. ábra)

2016-ban, 13 résztvevő bevonásával, az anti-xenofób országként számontartott Hollandiában letelepedett fiatal külföldi munkavállalók befogadó társadalomba való beágyazottságát vizsgáltam a kapcsolat rendszerükön keresztül, amihez a Lubbersés Molina (2007; 2010) által használt PSN-térkép (Wellman, 2007), és interjú módszerét alkalmaztam.

Ezúttal a kutatást hazai terepen folytattuk, Magyarországon élő, munkaviszonnyal rendelkező fiatal reguláris migránsok körében. A résztvevők hólabda módszerrel történő bevonása és lekérdezése az Eötvös Loránd Tudományegyetem Társadalom Tudományi Karának hallgatói csoportja által valósult meg*, jelen tanulmány adatainak feldolgozása, és elkészítése pedig Szabó Miklóssal közös munkánk eredménye.

*Köszönjük a kutatásban való közremüködést Dallos Virágnak, Horváth Richárdnak, Nagy Klárának, Pári Eszternek, Rákóczi Zoltánnak, Szecsődi Orsolyának, Szeltner Zsófiának, Székely Líviának, Tarnói Csengének és Telek Hannának.

\section{A kutatásról:}

\section{A kutatás aktualitása:}

A 2015-ös migrációs válság hatására tovább növekedett (minden rekordot megdöntött) xenofóbia, elöítéletesség (TÁRKI, 2016) természetesen gátolja a társadalmi integrációt, valamint a külföldiek lehetőségét a Host-országbeli kapcsolatok kialakítására, ami különböző kulturális- gazdasági - társadalmi javak (Bourdieu, 1987; Granovetter 1973, 1974; Angelusz \&Amp, Tardos 1998; Gyarmati 2009; Dávid- Huszti-Lukács, 2016) áramoltatásán túl, hozzájárulhatna az egyén szubjektív jóllétéhez (Utasi, 1999, 2004; Albert- Dávid, 1999, 2004, 2007, 2016; Dávid- Huszti- Lukács, 2016; etc.). A vizsgált fiatalokat fokozottan érinthetik az elöítéletekre alapozott sztereotípiák, ennek következtében a kirekesztés, emellett más, aktív- fizikailag is elérhető kapcsolatok hiányában az izoláció.

A kapcsolatok jelentőségét, sokrétü funkcióit, elengedhetetlen szerepét az integrációban különböző tudományok neves képviselői számtalanszor bebizonyították (Durkheim, 1982; Merton, 2002; Weber, 1982; 1987; Parsons, 1985; Habermas, 1994). 
A kapcsolatok értelmezésének egyik legelterjedtebb terminusa az erős- és gyenge kötések fogalma. Granovetter 1. a kölcsönhatások időtartama, 2. a kötések érzelmi intenzitása, intimitása és 3. a kölcsönösen nyújtott szolgáltatások jellege alapján különbözteti meg a gyenge- és az erös kötéseket egymástól (Granovetter, 1982).

Az erős kötéseknek tekintett kapcsolatok a kapcsolati erőforrás-áramlás során megszerzett és birtokolt státus megőrzésében, míg a gyenge kötések a státusok megszerzésében játszanak szerepet (Angelusz, Tardos, 1991; Granovetter, 1991; Lin, 1991). Az erös kapcsolatok biztosítják az intimitás, stabilitás, és bizalom érzését az egyén számára, segítik őt a megküzdésben, és támogatják a nehéz élethelyzetekben, emellett pedig biztosítják a fizikai- és pszichés jól-léthez szükséges javakat. A gyenge kapcsolatoknak elsődleges funkciója a társadalmi távolságok áthidalása, a közvetítés, illetve az információ-csere (Kawachi, 2006 in Dávid, Huszti, Lukács, 2016).

Aki azonban úgy dönt, hogy elhagyja az anyaországát, és egy idegen országban kezd új életet, annak rövid időn belül szembesülnie kell a ténnyel, hogy sok egyéb mellett szinte a teljes kapcsolathálózatát elveszítette, legalábbis ami a fizikai közelséget illeti. Bár a technikának köszönhetően lehetőségek tárháza áll rendelkezésre a kapcsolattartásra, ezeket elsősorban az erős kapcsolataink esetében használjuk, amelyek funkciója is kényszerüen átalakul a távolság következtében.

A Personal Social Network, vagy PSN-térkép lehetőséget kínál a bevándorló egyének kapcsolathálózati változásainak nyomonkövetésére. A Host-ország társadalmába történő integrációnak, a munkaeröpiaci integrácó, a nyelvtudás, a kultúra megismerése- elsajátítása mellett fontos mutatója, hogy az egyénnek sikerül-e „újraépítenie” a HOST- országban a networkjét, és továbbra is hozzájutnia a kapcsolatok által áramoltatott javakhoz, aktív, fizikailag is elérhető kapcsolatok formájában.

\section{Módszer:}

A PSN-térkép (Wellman, 2007), és interjú együttes alkalmazásának módszerét a Lubbers, - és Molina szerzőpáros néhány évvel ezelőtt sikeresen alkalmazta a Spanyolországban élő migránsok kapcsolathálózatának elemzésére (Lubbers, Molina, 2010). A térkép elkészítésének többszöri alkalmazásával, elsősorban 4 kategóriában (Host- Origin-Fellows-Transationals) követhetjük nyomon a kapcsolatok számának, típusának, funkcióinak, közelségének, a kapcsolathálózat összetételének változását. A fent említett négy kategóriát a következőképpen értelmezzük:

Host: Az új ország befogadó közege. Azok a kapcsolatok, akik a fogadó országban születtek és jelenleg is ott élnek.

Origin: Kibocsájtó közeg. Azok a kapcsolatok, akik az anyaországban születtek, és jelenleg is ott élnek.

Fellows: Hasonló kulturális közeg. Azok a kapcsolatok, akik az anyaországból származnak, és a befogadó országban élnek.

Transnationals: Mindenki más. Egyéb nemzetközi kapcsolatok.

A lekérdezés második része interjúból áll, aminek segítségével kiküszöbölhetőek az esetleges vakfoltok, és további információhoz juthatunk a migráció okait, és a szubjektív integráltság érzetet illetően. 
A használt módszer egyértelmüen kvalitatív-jellegü, reprezentativitás hiányában, és viszonylag kevés résztvevő bevonásának következtében eredményeinket nem áll szándékunkban a társadalom egészére értelmezni. Eddigi tapasztalataink alapján elmondható, hogy a lekérdezés során a résztvevők nagymértékben bevonódnak, szívesen mesélnek, így sok addicionális információhoz jutunk a konkrét kérdéseken túl. Ezáltal nagymennyiségü adat áll rendelkezésre, így sokrétü elemzési lehetőség nyílik a kapcsolati háló mélyebb- részletesebb- „minőségibb” megismerésére.

Jelen tanulmányban azt vizsgáltuk, hogy a megkérdezett magyarországi bevándorlók mekkora kapcsolathálózattal rendelkeznek, illetve sikerült-e integrálódniuk a befogadó ország társadalmába azáltal, hogy a kapcsolathálózatukban megjelennek a HOST-kapcsolatok. A magyar lekérdezés eredményeit a fenti dimenziókban összevetjük a hollandiai lekérdezés eredményeivel.

\section{Vizsgálati populáció:}

A mintába olyan egyének kerültek, akik 18 és 35 év közöttiek, nem magyar állampolgárok*, de rendelkeznek Magyarországon munkavállalási engedéllyel és bejelentett munkájuk van. A mintába hólabda mintavételi módszerrel kerültek az alanyok. Vannak olyan társadalmi jelenségek, amiket nem, vagy csak nagyon nehezen lehet lakossági listából választott mintán vizsgálni. Andorka ilyeneknek nevezi meg a ritka jelenségeket és a „rejtett populációkat” (Andorka, 2006) , mint esetünkben a külföldi munkavállalókat Magyarországon. Ilyen esetben a hólabda módszert ajánlja. A résztvevők demográfiai adatait az 1. táblázatban foglaltuk össze.

\begin{tabular}{|c|c|c|c|c|}
\hline & \multicolumn{2}{|c|}{$\begin{array}{l}\text { Amszterdami (NL) lekérdezés } \\
\text { (2015) }\end{array}$} & \multicolumn{2}{|c|}{$\begin{array}{l}\text { Budapesti (HU) } \\
\text { lekérdezés (2017) }\end{array}$} \\
\hline $\mathbf{N}=$ & \multicolumn{2}{|c|}{13 (7 külföldi, 6 holland) } & \multicolumn{2}{|c|}{30 ( 30 külföldi) } \\
\hline Átlagéletkor & \multicolumn{2}{|c|}{28,3} & \multicolumn{2}{|c|}{25,8} \\
\hline Életkor min. & \multicolumn{2}{|c|}{19} & \multicolumn{2}{|l|}{18} \\
\hline Életkor max & \multicolumn{2}{|c|}{35} & \multicolumn{2}{|l|}{33} \\
\hline Munkaviszonnyal rendelkezik & \multicolumn{2}{|c|}{$100 \%$} & \multicolumn{2}{|l|}{$100 \%$} \\
\hline Nő-Férfi arány & \multicolumn{2}{|c|}{$54 \%-46 \%$} & \multicolumn{2}{|l|}{$50 \%-50 \%$} \\
\hline \multirow{5}{*}{ Végezettség } & DMD & 2 & $\mathrm{PhD} / \mathrm{MD} / \mathrm{DMD}$ & 3 \\
\hline & $\mathrm{MA} / \mathrm{MSc}$ & 6 & $\mathrm{MA} / \mathrm{MSc}$ & 10 \\
\hline & $\mathrm{BA} / \mathrm{BSC}$ & 4 & $\mathrm{BA} / \mathrm{BSC}$ & 8 \\
\hline & \multirow{2}{*}{ HAVO } & \multirow{2}{*}{1} & OKJ & 1 \\
\hline & & & Érettségi & 8 \\
\hline
\end{tabular}

1. táblázat A magyar- és holland részvevők adatai.

* Magyarországon kívül született és nőtt fel, viszont jelenleg Magyarországon él minimum egy éve, maximum 10 éve, és ez tervei szerint nem fog megváltozni az elkövetkező egy évben.

\section{Eredmények}

Bár a fent ismertetett módszer segítségével kapott adatok változatos elemzési perspektívákat tesznek lehetővé, a tanulmány terjedelmi korlátait figyelembe véve ezúttal 
csak a network méretére és a Host-Origin-Fellows-Transnational (továbbiakban H-OF-T) kapcsolatok arányának elemzésére fókuszáltunk.

Az adatok feldolgozása során mind a magyar, mind a holland mintát figyelembe vettük, és célunk volt azok objektív összehasonlítása. A módszertan annyiban különbözött a két lekérdezés során, hogy az első kutatásban hollandokat (azaz Host, nem pedig bevándorló) alanyokat is a mintába vettünk. A kutatás első (pilot-jellegü) fázisában ennek a célja kontroll-jellegü volt: kíváncsiak voltunk, hogy a hollandok networkjében megjelennek-e külföldi alterek. Ez a magyarországi kutatásnak egyelöre nem része, azonban az itthoni lekérdezés tervezett következő lépcsőfoka. Ennek ellenére, amíg ez az adat nemáll rendelkezésre mindkét mintában, a holland mintának ezen részét figyelmen kívül kell hagynunk.

\section{A network méretének elemzése:}

A 2. táblázat adataiból megállapíthatjuk, hogy a Magyarországon megkérdezettek átlagosan 21,4, összesen pedig 621 altert említettek a lekérdezéskor. Átlagosan egy megkérdezett személy 8,33 nagyon közeli és 12,37 valamelyest közeli kapcsolatot említett.

\begin{tabular}{|l|r|r|r|r|r|r|r|}
\hline \multicolumn{1}{|c|}{ HU } & $\begin{array}{c}\text { Network } \\
\text { méret }\end{array}$ & $\begin{array}{c}\text { Nagyon } \\
\text { közeli }\end{array}$ & $\begin{array}{c}\text { Valame- } \\
\text { lyest közeli }\end{array}$ & Host & Origin & Fellow & Transnational \\
\hline TOTAL & 621 & 250 & 371 & 213 & 188 & 92 & 125 \\
\hline Átlag & 21,41 & 8,33 & 12,37 & 7,34 & 6,48 & 3,17 & 4,31 \\
\hline Min & 7 & 1 & 4 & 0 & 0 & 0 & 0 \\
\hline Max & 45 & 17 & 34 & 40 & 19 & 11 & 15 \\
\hline
\end{tabular}

2. táblázat- Magyarországi lekérdezés- Összesített. Forrás: saját szerk. Szabó M. (2017)

A hollandiai lekérdezés mintájában szereplő ego-k network- paramétereinek átlagos eloszlása a 3. táblázatban látható: itt az átlagos network méret 14,7 altert tartalmazott. (3. táblázat) A nagyon közeli kapcsolatok átlaga 9,3; a valamelyest közeliek átlaga pedig 5,4 személy (3. táblázat).

Érdekes különbség a fenti adatok alapján, hogy a Magyarországon folytatott kutatás résztvevői jóval magasabb network-méret átlaggal rendelkeznek, mint a Hollandiában lekérdezettek (4. táblázat) . A magyar 21,41 és a holland 14,7 átlag mutatja, hogy több mint 6 alterrel nagyobb a kapcsolati hálója a Magyarországon vizsgált bevándorlók átlagkapcsolatának, ami a megkérdezett holland átlag 145\%-a. Különösen meglepő volt számunkra ez az adatkülönbség, ismerve a magyarországi idegenellenesség mutatóit (idegenellenes 53\%; idegenbarát $1 \%$; TÁRKI, 2016).

\begin{tabular}{|c|c|c|c|c|c|c|c|}
\hline NL & $\begin{array}{c}\text { Network } \\
\text { méret }\end{array}$ & $\begin{array}{c}\text { Nagyon } \\
\text { közeli }\end{array}$ & $\begin{array}{c}\text { Valame- } \\
\text { lyest közeli }\end{array}$ & Host & Origin & Fellows & Transnational \\
\hline TOTAL & 103 & 65 & 38 & 10 & 59 & 8 & 26 \\
\hline Átlag & 14,71 & 9,29 & 5,43 & 1,43 & 8,43 & 1,14 & 3,71 \\
\hline Min & 8 & 4 & 3 & 0 & 4 & 0 & 0 \\
\hline Max & 20 & 14 & 9 & 3 & 14 & 4 & 10 \\
\hline
\end{tabular}

Forrás: Saját szerk, 2017.

3. táblázat- Hollandiai lekérdezés, külföldiek adatai, 


\begin{tabular}{|l|r|r|r|r|c|c|c|}
\hline \multicolumn{4}{|c|}{ Magyar minta } & \multicolumn{4}{c|}{ Holland minta } \\
\hline EGO & $\begin{array}{c}\text { Network } \\
\text { méret }\end{array}$ & $\begin{array}{c}\text { Nagyon } \\
\text { közeli }\end{array}$ & $\begin{array}{c}\text { Valamelyest } \\
\text { közeli }\end{array}$ & EGO & $\begin{array}{c}\text { Network } \\
\text { méret }\end{array}$ & $\begin{array}{c}\text { Nagyon } \\
\text { közeli }\end{array}$ & $\begin{array}{c}\text { Valame- } \\
\text { lyest } \\
\text { közeli }\end{array}$ \\
\hline Total & 621 & 250 & 371 & Total & 103 & 65 & 38 \\
\hline Átlag & 21,41 & 8,33 & 12,37 & Átlag & 14,71 & 9,29 & 5,43 \\
\hline Min & 7 & 1 & 4 & Min & 8 & 4 & 3 \\
\hline Max & 45 & 17 & 34 & Max & 20 & 14 & 9 \\
\hline
\end{tabular}

Forrás: saját szerk, 2017.

4. táblázat Nagyon közeli és valamelyest közeli kapcsolatok, összesített.

A nagyon közeli kapcsolatok között a holland minta 9,3-as átlaga magasabb, mint a magyar 8,33, azonban a valamelyest közeli kapcsolatok 5,4 és 12,37 arányban oszlik meg a magyar minta javára (okozva a teljes network méretének nagymértékü eltérését). (4. táblázat)

Ez a nagy eltérés, ami a valamelyest közeli kapcsolatok elemzésénél felmerül további kérdéseket vet fel. Felettébb érdekes lenne megnézni a valamelyest közeli és a nagyon közeli kapcsolatok H-O-F-T eloszlását, hogy választ kapjunk arra a kérdésre, hogy kik alkotják föként a nagyon közeli kapcsolatokat, ahol jelentős eltérést tapasztaltunk a két minta esetében.

\section{A kapcsolatháló milyenségének vizsgálata a Host-Origin-Fellows- Transnationals kategóriákon belül:}

Az H-O-F-T kapcsolatok eloszlása különösen érdekes. Az 5. táblázat azt mutatja, hogy egy egonak a magyar mintában átlagosan 7,34 Host, 6,48 Origin, 3,17 Fellow és 4,31 Transnationals kapcsolata van. Azonban ez csak a mintánk alapján készült átlagos eloszlást veszi alapul, az egyéni szinten folytatott elemzés után észrevehetjük, hogy az egyéni szinten vizsgált arányok nem egyeznek meg az átlagos megoszlással, hanem másféle módon oszlanak meg. Az egok jelentős többségénél megfigyelhető, hogy bizonyos esetekben a H-O-F-T kategóriák valamelyikében (néha több esetben is) nagyon alacsony a megnevezett alterek száma, másokban pedig kiugróan magas.(Melléklet III- 3. ábra, Melléklet VI.- 4.ábra )

A holland kutatás eredményeit ugyanilyen szempontok alapján dolgoztuk fel. Az ott kapott mintában a network H-O-F-T kategóriánkénti átlaga a következő volt (5. táblázat): a Host kapcsolatok átlaga 1,43; az Origin kapcsolatoké 8,43; a Fellows kapcsolatoké 1,14 és a Transnationals kapcsolatok átlaga pedig 3,71 (5. táblázat).

\begin{tabular}{|c|c|c|c|c|c|c|c|c|c|}
\hline \multicolumn{5}{|c|}{ Magyar minta } & \multicolumn{5}{c|}{ Holland minta } \\
\hline Ego & Host & Origin & Fellow & $\begin{array}{c}\text { Trans- } \\
\text { national }\end{array}$ & Ego & Host & Origin & Fellow & $\begin{array}{c}\text { Trans- } \\
\text { national }\end{array}$ \\
\hline Total & 213 & 188 & 92 & 125 & Total & 10 & 59 & 8 & 26 \\
\hline Átlag & 7,34 & 6,48 & 3,17 & 4,31 & Átlag & 1,43 & 8,43 & 1,14 & 3,71 \\
\hline Min & 0 & 0 & 0 & 0 & Min & 0 & 4 & 0 & 0 \\
\hline Max & 40 & 19 & 11 & 15 & Max & 3 & 14 & 4 & 10 \\
\hline
\end{tabular}

Forrás: saját szerk, 2017.

5. táblázat H-O-F-T összesített. 
A fentiek alapján egyértelmúen kitünik, hogy a két országban megkérdezettek szociális hálója nagy mértékben különbözik a mérete és a H-O-F-T kapcsolatok eloszlása szempontjából is. A holland mintában az átlagok közül legjobban az Origin kapcsolatok tünnek ki, ami a Host, a Fellows és a Transnationals átlagoknak a többszöröse. A magyar adatoknál az átlagok közötti különbség ehhez képest elhanyagolható. Ez alapján megállapítható, hogy a Magyarországon megkérdezettek átlagosan több kapcsolattal rendelkeznek, tehát az integrációjuk ebböl a szempontból sikeresebbnek mondható.

Mindenképpen szót kell ejtenünk azonban a Host-Origin kapcsolatok megoszlásáról is. A Host és Origin kapcsolatok azok, amelyek aránya egy egyén integrációját főként meghatározhatják. A magyar mintában a Host-Origin átlagok 7,34 - 6,48, a holland mintában pedig 1,43 - 8,43 arányban oszlanak meg, ami nem csak arányaiban tér el szignifikánsan, hanem a kapcsolati átlagok aránya megfordul.

\section{Záró gondolatok}

Ezekről a számokról persze lehetne vitatkozni: az eltéréseket magyarázni lehetne a két minta különbözőségeivel (eltérő nemzetiségüek a mintában, eltérő létszámú ego a mintában, a mintavétel módszere nem ad reprezentatív mintát, etc.), vagy a magyarholland társadalmi és kulturális háttér nagy eltérésével, amire ebben a tanulmányban nem volt módunk kitérni. Itt szeretnénk ismételten hangsúlyozni, hogy a kapott eredményeket nem áll szándékunkban a két társadalom egészére értelmezni. Amit viszont konklúzióként érdemesnek tartunk megjegyezni, hogy a fenti adatok újabb bizonyítékként értelmezhetőek arra, hogy a kvantitatív módszerek mellett érdekes és szükséges kvalitatív dimenziókban is vizsgálni a társadalmi jelenségeket, hiszen a kutatási fókusz mélyebb- részletesebb megismerése mellett, az esetleges ellentmondások újabb elemzési dimenziókat is kijelölhetnek.

\section{Bibliográfia Irodalmi hivatkozások}

1. Albert, F., Dávid, B. (2016): A magyarországi kapcsolathálózati struktúrák jellemzői 2015-ben. Socio.hu, 2016/3, 22-42.

2. Albert, F., Dávid, B.(2004): A kapcsolati tőke dimenziói etnikai metszetben. In Kolosi T., Tóth I. Gy., Vukovich Gy. (szerk.) Társadalmi Riport, Budapest: TÁRKI, 351-372.

3. Albert, F., Dávid, B. (1999) A bizalmas kapcsolatokról. In Szivós P., Tóth I. Gy. (szerk.) Monitor 1999. Budapest: TÁRKI, 218-230.

4. Albert, F., Dávid, B. (2007): Embert barátjáról. A barátság szociológiája. Budapest: Századvég.

5. Albert, F., Dávid, B. (2012): Az interperszonális kapcsolathálózati struktúra átrendeződése Magyarországon. In Kovách I., Dupcsik Cs., P. Tóth T., Takács J. (szerk) 
Társadalmi integráció a jelenkori Magyarországon. Budapest: Argumentum MTA Társadalomtudományi Kutatóközpont Szociológiai Intézet, 343-356.

6. Albert, F., Dávid, B. (2015) : Mikromiliő integrációs megközelítésben .A személyes kapcsolatokra vonatkozó eddigi kutatási eredmények áttekintése. Socio.hu, 2015/4, 1-11.

7. Andorka, R. (2006) - Bevezetés a szociológiába, 48. o.

8. Angelusz, R., Tardos R. (1998): A kapcsolathálózati erőforrások átrendeződésének tendenciái a kilencvenes években. In: Kolosi, T. et al. (szerk.) Társadalmi riport 1998. Budapest: TÁRKI. 237-256.

9. Angelusz, R., Tardos, R. (1991) A magyarországi kapcsolathálózatok néhány sajátossága. In Angelusz R., Tardos R. (szerk.) Hálózatok stílusok, struktúrák. Budapest: ELTE Szociológiai Intézet - Magyar Közvéleménykutató Intézet, 55-73.

10. Bourdieu, P. (1983) Gazdasági tőke, kulturális tőke, társadalmi tőke. In: Angelusz, R. (szerk.) (1999) A társadalmi rétegződés komponensei. Budapest: Új Mandátum Könyvkiadó. 156-177.

11. Bourdieu, P. (1998; 1983). Gazdasági tőke, kulturális tőke, társadalmi tőke. Megj.: Lengyel, Szántó 1998.

12. Brandes, U., Lerner, J., Lubbers, M. J., McCarty, C., Molina, J. L. \& Nagel, U. (2010): Recognizing modes of acculturation in personal networks of migrants. Procedia Social and Behavioral Sciences, 4, 4-13.

13. Dávid, B., Huszti, É., Lukács, Á. (2016): Társas kapcsolatok jelentősége a társadalmi integrációban. In Acta Medicinae et Socilogica. Nyíregyháza: Debreceni Egyetem Egészségügyi Kar.

14. Durkheim, E. (1982): Az öngyilkosság. Budapest: Közgazdasági és Jogi Kiadó.

15. Granovetter, M. S. (1973): The Strenght of Weak Ties. American Journal of Sociology, 78(6): 1360-1380.

16. Granovetter, M. S. (1974): Getting a Job. Study of Contacts and Careers. Cambridge: Harvard University Press.

17. Granovetter, M. S. (1982): A gyenge kötések ereje. A hálózatelmélet felülvizsgálata. In: Angelusz, R. \& Tardos, R. (szerk.) (1991) Társadalmak rejtett hálózata. Budapest: Magyar Közvéleménykutató Intézet. 371-400.

18. Habermas, J. (1994): Válogatott tanulmányok. Budapest: Atlantisz.

19. Hogan, B., Carrasco, J.A., Wellman, B. (2007): Visualizing Personal Networks: Working with Participant-aided Sociograms. Field Methods, 19. p. 116-144.

20. Huszti, É.: Megismer-hetem: A személyes kapcsolathálózat feltárásának új formája: kapcsolati napló. Debreceni Egyetemi Kiadó, 2015.

21. Lin, N. (2008): A network theory of social capital. In: Castiglione, D., van Deth, J. W. \& Wolleb, G. (szerk.) The Handbook of Social Capital. Oxford: Oxford University Press. 50-69.

22. Lubbers, M. J., Molina, J.L, Lerner,J., Brandes, U., Ávila, J., McCarty, C. (2010): Longitudinal analysis of personal networks. The case of Argentinean migrants in Spain in Social Networks, 32 (1), 91-104.

23. Lubbers, M. J., Molina, J. L. \& McCarty, C. (2007): Personal Networks and Ethnic Identifications: The Case of Migrants in Spain. International Sociology, 22(6), 721-741. 
24. Merton, R. K. (2002): Társadalomelmélet és társadalmi struktúra. Budapest: Osiris Kiadó.

25. Parsons, T. (1985): A társadalmi rendszerről. Szociológiai Füzetek 45.

26. Szabó, D. ( 2016): Barátság-Magyar és holland egyetemista fiatalok barátkozási szokásainak vizsgálata: mennyiségi és minőségi szempontból. In Diáktudomány: Verzár Frigyes Szakkollégium hallgatóinak tudományos munkái 2015-16. 117-146.

27. Szabó, D. (2017): Networking- Integráció a munka világába a személyes kapcsolathálózaton keresztül, holland, - és Hollandiában letelepedett fiatal munkavállalók esetében. In: Acta Medicinae et Sociologica: Útban a cél felé. Nyíregyháza: Debreceni Egyetem Egészségügyi kar

28. Utasi Á., Páthy Á., Hári P. (2004): A kapcsolatok nemzetközi trendje másfél évtized távlatában. In Utasi Á. (szerk.) Kapcsolatok nemzetközi metszetben. Budapest: MTA Politikai Tudományok Intézete, 9-39.

29. Utasi, Á. (1990): Baráti kapcsolatok. In Andorka R., Kolosi T., Vukovich Gy. (szerk.) Társadalmi riport. Budapest: TÁRKI, 475-487.

30. Weber, M. (1987): Gazdaság és társadalom 1. Szociológiai kategóriatan. Budapest: Közgazdasági és Jogi Kiadó.

Internetes hivatkozások: http://

1. Migráció Kutató Intézet: Migrációs várakozások 2017-re. Utoljára látogatva: (2017. 02.12.)

https://www.migraciokutato.hu/ hu/2017/02/22/migracios-varakozasok-2017-re/

2. Orbán Annamária és Szántó Zoltán 2005: Társadalmi tőke. In: Erdélyi Társadalom 2005/2. 55-70.o. Utoljára látogatva: (2017. 11. 26.)

3. www.socialnetwork.hu/cikkek/OrbanSzanto2007.htm

4. http://www.tarki.hu/hu/news/2016/kitekint/20160404_idegen.html Utoljára látogatva: (2017. 11. 27.)

Adatbázisok:

1. TÁRKI, 2016

2. EUROBAROMÉTER 
Melléklet I.

1. ábra: Nemzetközi migránsok globális száma

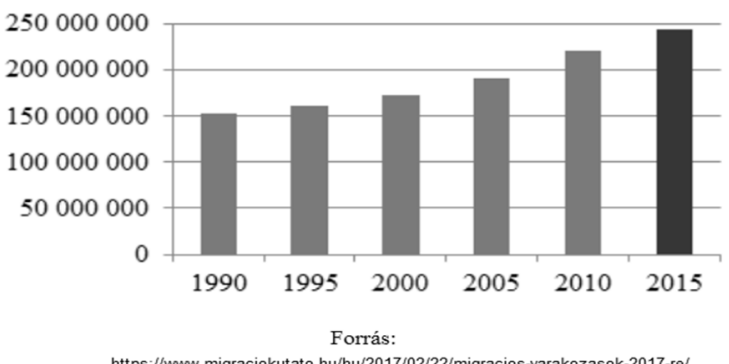

https://mww.migraciokutato.hu/hu/2017/02/22/migracios-varakozasok-2017-re/

Melléklet II.

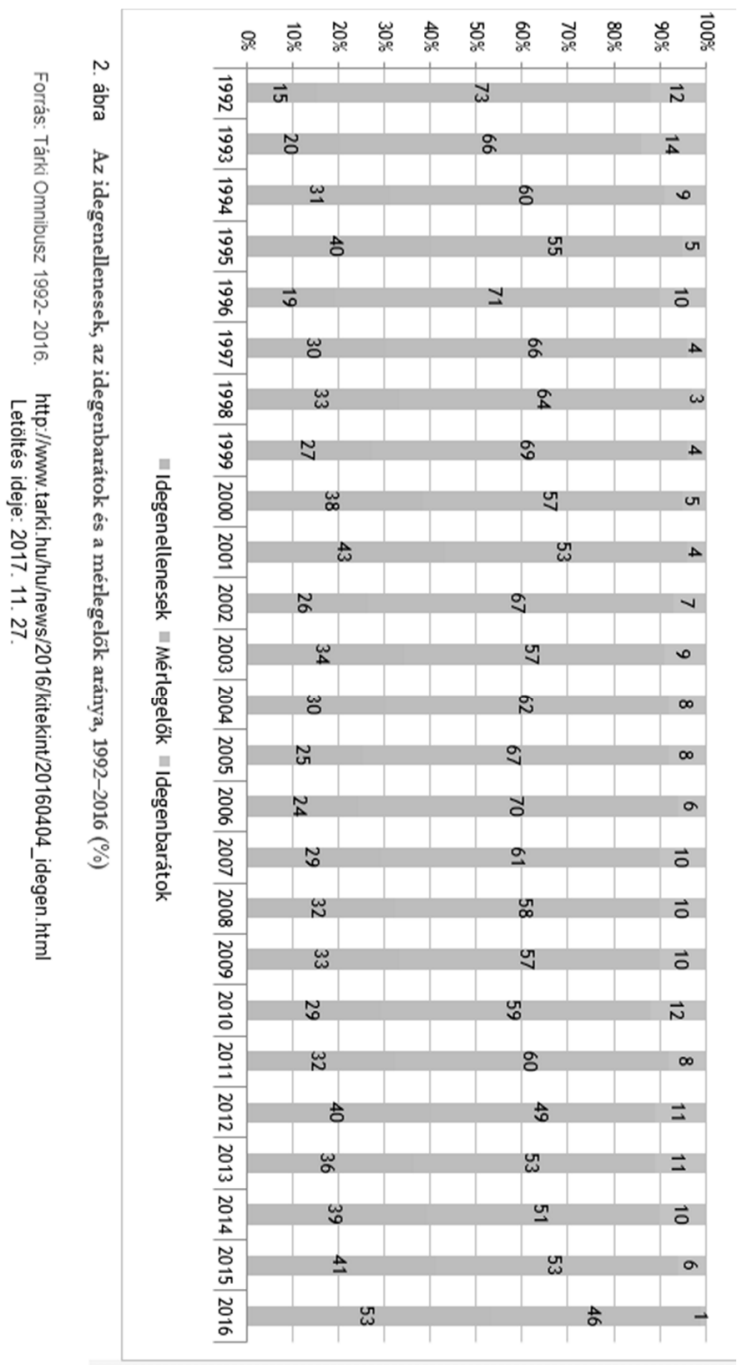




\section{Melléklet III.}

\begin{tabular}{|c|c|c|c|c|c|c|c|c|c|c|c|}
\hline Nemzetiség & Nem & Kor & Végzettség & Munka & $\begin{array}{c}\text { Network } \\
\text { méret }\end{array}$ & $\begin{array}{c}\text { Nagyon } \\
\text { közeli }\end{array}$ & $\begin{array}{c}\text { Valamelyest } \\
\text { közeli }\end{array}$ & Host & Origin & Fellow & Transnational \\
\hline Anita / Román & $n$ & 20 & érettségi & alkalmi munka & \begin{tabular}{|r|}
18 \\
\end{tabular} & $\begin{array}{r}7 \\
\end{array}$ & 11 & 0 & 13 & 5 & 0 \\
\hline Zsófi / Román & n & 21 & érettségi & ruhabolti eladó & 17 & 10 & 7 & 0 & 10 & 7 & 0 \\
\hline Andrei /Román & $f$ & 31 & MA & Opex specialista & 11 & 5 & 6 & 3 & 5 & 1 & 0 \\
\hline Roxy / Román & n & 31 & MA & IT & 12 & 7 & 5 & 3 & 5 & 3 & 1 \\
\hline Júlia / Román & $n$ & 20 & érettségi & ruhabolti eladó & 24 & 11 & 13 & 2 & 12 & 8 & 2 \\
\hline Bogi / Szlovák & n & 22 & BA-Bárczi & Marketing admin & 21 & 13 & 8 & 12 & 9 & 0 & 0 \\
\hline Makréta / Cseh & $n$ & 22 & érettségi & $\begin{array}{l}\text { hallgató és } \\
\text { orvossegéd }\end{array}$ & 31 & 15 & 16 & 7 & 19 & 1 & 4 \\
\hline Jana / Ukrán & n & 23 & MA & adminisztrátor & 45 & 11 & 34 & 40 & 1 & 4 & 0 \\
\hline Elena / Ukrán & $n$ & 31 & MA & HR vezetö & 16 & 7 & 9 & 3 & 6 & 0 & 7 \\
\hline Andrij / Ukrán & $\mathrm{f}$ & 24 & érettségi & adminisztrátor & 33 & 16 & 17 & 26 & 0 & 5 & 2 \\
\hline Ági / Ukrán & $n$ & 20 & érettségi & edzö & 20 & 10 & 10 & 18 & 0 & 2 & 0 \\
\hline Nisrine / Francia & n & 21 & BA & call center & 31 & 10 & 21 & 1 & 14 & 1 & 15 \\
\hline Davide / Olasz & $f$ & 32 & BSC & $\begin{array}{l}\text { projektmanager/prog } \\
\text { ramozó }\end{array}$ & 25 & 14 & 11 & 12 & 4 & 0 & 9 \\
\hline $\begin{array}{l}\text { Francois / } \\
\text { Belgium }\end{array}$ & $f$ & 28 & $\mathrm{PhD}$ & post-doc kutató & 13 & 5 & 8 & 0 & 8 & 0 & 5 \\
\hline Ben / UK & $f$ & 26 & OKJ & $\begin{array}{l}\text { ügyfélszolgálati } \\
\text { képviselö }\end{array}$ & 15 & 5 & 10 & 3 & 11 & 0 & 1 \\
\hline Clare /USA & $n$ & 26 & BA & call center, library & 30 & 7 & 23 & 4 & 13 & 1 & 12 \\
\hline Anna / USA & n & 30 & BA & Digitális marketing & 35 & 15 & 20 & 8 & 13 & 2 & 12 \\
\hline Alex / USA & $f$ & 26 & MA & tartalommarketing & 11 & 7 & 4 & 2 & 3 & 2 & 4 \\
\hline Michael / USA & $f$ & 26 & MA & Elektromérnök & 11 & 1 & 10 & 2 & 5 & 2 & 2 \\
\hline Sion /Namíbiai & $f$ & 27 & BSC & IT & 15 & 5 & 10 & 4 & 7 & 0 & 4 \\
\hline Kaleab / Etióp & $f$ & 33 & $\mathrm{PhD}$ & $\begin{array}{l}\text { egyetemi tanár/ } \\
\text { ifjúsági koordinátor }\end{array}$ & 9 & 3 & 6 & 2 & 4 & 1 & 2 \\
\hline Sanad / Libiai & $f$ & 18 & Középszint & bolti eladó & 7 & 3 & 4 & 2 & 0 & 5 & 0 \\
\hline $\begin{array}{l}\text { Nguyen / } \\
\text { Vietnam } \\
\end{array}$ & $f$ & 27 & BA & informatikus & 27 & 11 & 16 & 19 & 0 & 7 & 1 \\
\hline Nhut / Vietnam & $f$ & 29 & $\mathrm{PhD}$ & $\begin{array}{l}\text { Postdoctoral } \\
\text { researcher }\end{array}$ & 9 & 3 & 6 & 0 & 3 & 1 & 5 \\
\hline Rodrigo / Mexico & $f$ & 21 & |érettségi & call center & 13 & 7 & 6 & 5 & 4 & 3 & 1 \\
\hline Katya/ Orosz & n & 26 & BA & $\begin{array}{l}\text { Online Marketing } \\
\text { Specialista }\end{array}$ & 18 & 8 & 10 & 4 & 4 & 0 & 10 \\
\hline Hoa / Vietnámi & n & 26 & MA & könyvtáros, tanár & 35 & 6 & 29 & 14 & 0 & 11 & 10 \\
\hline Gulara / Azerbj & n & 29 & MA & $\begin{array}{l}\text { Senior Finance } \\
\text { Assistant }\end{array}$ & 16 & 3 & 13 & 5 & 1 & 4 & 6 \\
\hline Hossein / Irán & $f$ & 32 & MA & fogorvos & 31 & 17 & 14 & 8 & 8 & 9 & 5 \\
\hline Zlata / Jordán & $f$ & 28 & MA & tréner & 22 & 8 & 14 & 4 & 6 & 7 & 5 \\
\hline Total & $15 n-15 f$ & $x$ & $x$ & $x$ & 621 & 250 & 371 & 213 & 188 & 92 & 125 \\
\hline Átlag & $\mathrm{x}$ & 25,87 & $x$ & $\mathrm{x}$ & 21,41 & 8,33 & 12,37 & 7,34 & 6,48 & 3,17 & 4,31 \\
\hline Min & $x$ & 18 & $x$ & $x$ & 7 & 1 & 4 & 0 & 0 & 0 & 0 \\
\hline Max & $x$ & 33 & $\mathrm{x}$ & $\mathrm{x}$ & 45 & 17 & 34 & 40 & 19 & 11 & 15 \\
\hline
\end{tabular}

3. ábra Magyarországi lekérdezés- Összesített, N=30, Forrás: saját szerkesztés, Szabó M. (2017)

\section{Melléklet IV.}

\begin{tabular}{|c|c|c|c|c|c|c|c|}
\hline \multicolumn{4}{|c|}{ Magyar minta } & \multicolumn{4}{|c|}{ Holland minta } \\
\hline EGO & Nem & $\begin{array}{c}\text { Nagyon } \\
\text { közeli }\end{array}$ & $\begin{array}{c}\text { Valamelyest } \\
\text { közeli }\end{array}$ & EGO & $\begin{array}{c}\text { Network } \\
\text { méret }\end{array}$ & $\begin{array}{c}\text { Nagyon } \\
\text { közeli }\end{array}$ & $\begin{array}{c}\text { Valamelyest } \\
\text { közeli }\end{array}$ \\
\hline $\begin{array}{l}\text { Anita / } \\
\text { Román }\end{array}$ & $\mathrm{n}$ & 7 & 11 & Ditta (HU) & 8 & 4 & 4 \\
\hline $\begin{array}{l}\text { Zsófi / } \\
\text { Román }\end{array}$ & n & 10 & 7 & $\begin{array}{c}\text { Hannelore } \\
\text { (RO) }\end{array}$ & 12 & 7 & 5 \\
\hline $\begin{array}{l}\text { Andrei } \\
\text { /Román }\end{array}$ & $f$ & 5 & 6 & Valeria (IT) & 15 & 10 & 5 \\
\hline $\begin{array}{l}\text { Roxy / } \\
\text { Román }\end{array}$ & n & 7 & 5 & Marta (PL) & 16 & 8 & 8 \\
\hline $\begin{array}{l}\text { Júlia / } \\
\text { Román }\end{array}$ & $\mathrm{n}$ & 11 & 13 & Gunar (D) & 14 & 11 & 3 \\
\hline $\begin{array}{l}\text { Bogi / } \\
\text { Szlovák }\end{array}$ & n & 13 & 8 & Tamir (NL-I) & 20 & 11 & 9 \\
\hline $\begin{array}{l}\text { Makréta / } \\
\text { Cseh }\end{array}$ & n & 15 & 16 & $\begin{array}{c}\text { Giuseppe } \\
\text { (IT) }\end{array}$ & 18 & 14 & 4 \\
\hline
\end{tabular}




\begin{tabular}{|c|c|c|c|c|c|c|c|}
\hline \multicolumn{4}{|c|}{ Magyar minta } & \multicolumn{4}{|c|}{ Holland minta } \\
\hline EGO & Nem & $\begin{array}{c}\text { Nagyon } \\
\text { közeli }\end{array}$ & \begin{tabular}{|c|}
$\begin{array}{c}\text { Valamelyest } \\
\text { közeli }\end{array}$ \\
\end{tabular} & EGO & $\begin{array}{c}\text { Network } \\
\text { méret }\end{array}$ & $\begin{array}{c}\text { Nagyon } \\
\text { közeli }\end{array}$ & $\begin{array}{c}\text { Valamelyest } \\
\text { közeli }\end{array}$ \\
\hline Jana / Ukrán & n & 11 & 34 & & & & \\
\hline $\begin{array}{l}\text { Elena / } \\
\text { Ukrán }\end{array}$ & $n$ & 7 & 9 & & & & \\
\hline $\begin{array}{l}\text { Andrij / } \\
\text { Ukrán }\end{array}$ & $f$ & 16 & 17 & & & & \\
\hline Ági / Ukrán & $n$ & 10 & 10 & & & & \\
\hline $\begin{array}{l}\text { Nisrine / } \\
\text { Francia }\end{array}$ & $n$ & 10 & 21 & & & & \\
\hline $\begin{array}{l}\text { Davide / } \\
\text { Olasz }\end{array}$ & $f$ & 14 & 11 & & & & \\
\hline $\begin{array}{l}\text { Francois / } \\
\text { Belgium }\end{array}$ & $f$ & 5 & 8 & & & & \\
\hline Ben / UK & $f$ & 5 & 10 & & & & \\
\hline Clare /USA & n & 7 & 23 & & & & \\
\hline Anna / USA & $n$ & 15 & 20 & & & & \\
\hline Alex / USA & $f$ & 7 & 4 & & & & \\
\hline $\begin{array}{l}\text { Michael / } \\
\text { USA }\end{array}$ & $f$ & 1 & 10 & & & & \\
\hline $\begin{array}{l}\text { Sion } \\
\text { /Namíbiai } \\
\end{array}$ & $f$ & 5 & 10 & & & & \\
\hline $\begin{array}{l}\text { Kaleab / } \\
\text { Etióp } \\
\end{array}$ & $f$ & 3 & 6 & & & & \\
\hline $\begin{array}{l}\text { Sanad / } \\
\text { Líbiai }\end{array}$ & $f$ & 3 & 4 & & & & \\
\hline $\begin{array}{l}\text { Nguyen / } \\
\text { Vietnam }\end{array}$ & $f$ & 11 & 16 & & & & \\
\hline $\begin{array}{l}\text { Nhut / } \\
\text { Vietnam }\end{array}$ & $f$ & 3 & 6 & & & & \\
\hline $\begin{array}{l}\text { Rodrigo / } \\
\text { Mexico } \\
\end{array}$ & $f$ & 7 & 6 & & & & \\
\hline Katya/Orosz & $n$ & 8 & 10 & & & & \\
\hline $\begin{array}{l}\text { Hoa / } \\
\text { Vietnámi } \\
\end{array}$ & $n$ & 6 & 29 & & & & \\
\hline $\begin{array}{l}\text { Gulara / } \\
\text { Azerbj }\end{array}$ & $n$ & 3 & 13 & & & & \\
\hline $\begin{array}{l}\text { Hossein / } \\
\text { Irán } \\
\end{array}$ & $f$ & 17 & 14 & & & & \\
\hline $\begin{array}{l}\text { Zlata / } \\
\text { Jordán } \\
\end{array}$ & $f$ & 8 & 14 & & & & \\
\hline Total & $15 n-15 f$ & 250 & 371 & Total & 103 & 65 & 38 \\
\hline Átlag & $\mathrm{x}$ & 8,33 & 12,37 & Átlag & 14,71 & 9,29 & 5,43 \\
\hline Min & $x$ & 1 & 4 & Min & 8 & 4 & 3 \\
\hline Max & $\mathrm{x}$ & 17 & 34 & Max & 20 & 14 & 9 \\
\hline
\end{tabular}

4. ábra Nagyon közeli és Valamelyest közeli kapcsolatok- magyar és holland minta - összesitett Forrás: Saját szerk, 2017. 